\title{
DNA probe analysis for carrier detection and prenatal diagnosis of Duchenne muscular dystrophy: a standard diagnostic procedure
}

\author{
E BAKKER*, E J BONTEN*, L F DE LANGE*, H VEENEMA*, \\ D MAJOOR-KRAKAUER $\dagger, M$ H HOFKER*, G J B VAN OMMEN*, \\ AND P L PEARSON* \\ From *the Department of Human Genetics, Sylvius Laboratories, 2333 AL Leiden; and the Department of \\ Clinical Genetics, University Hospital Dijkzigt, Rotterdam, The Netherlands.
}

SUMmARY Thirteen marker loci localised on the short arm of the $\mathrm{X}$ chromosome are available for use in genetic studies for Duchenne muscular dystrophy (DMD). This large number of probes detecting about 20 RFLPs encouraged us to set up a standard procedure using a sequence of selected probes and restriction enzymes for the diagnosis of DMD families. The application of DNA probe analysis for carrier detection and prenatal diagnosis, involving 61 pedigrees of both familial and isolated cases, has yielded the following results. Carrier detection using flanking markers was possible in more than $75 \%$ of the cases (104 out of 136 females) with a reliability of better than $98 \%$. Prenatal diagnosis was possible in $95 \%$ of the cases (65 out of 68 proven carriers or women at risk). Twenty-three prenatal diagnoses were performed on male fetuses; 13 appeared to have a low risk for DMD $(<1 \%)$ and thus the pregnancies continued. Seven have since come to term and the male infants have normal CK levels. The genetic distances of the loci relative to the $D M D$ locus and their order on the short arm of the $\mathrm{X}$ chromosome were deduced from our total DMD family material and are not significantly different from those reported earlier. For 754 (DXS84) we found a genetic distance of $5 \mathrm{cM}$ with a lod score of +12.4 and $95 \%$ confidence limits between 2 and $12 \mathrm{cM}$. Similar data were obtained for pERT87 (DXS164), suggesting that in our family material both loci are tightly linked. Multiply informative recombinations showed that both 754 and pERT87 map proximal to the DMD mutations in the cases studied. The high frequency of DMD mutations and its relation to the observed instability in this part of the genome will be discussed. Unequal crossing over is proposed as one of the mechanisms contributing to the high mutation frequency.

Duchenne muscular dystrophy (DMD) is a severe, $\mathrm{X}$ linked recessive, neuromuscular disorder. The high incidence in the population (one in 3000 males ${ }^{1}$ ) is caused by a high mutation rate of approximately 1 in 10000 . The observed instability of this locus, and the basic biochemical defect responsible for the Duchenne phenotype, are not yet understood. For many years, carrier detection for DMD has been based on pedigree analysis and on serum creatine kinase (CK) levels, even though CK determination displays both variability ${ }^{2}$ and overlap between normals and carriers in around $30 \%$ of obligate carriers. Since Davies et $\mathrm{al}^{3}$ described the first RFLPs located in Xp and flanking $D M D$,

Received for publication 1 August 1986.

Accepted for publication 4 August 1986 other RFLPs in Xp have been reported to be potentially useful for diagnosis of DMD. ${ }^{45} \mathrm{We}$ have performed both carrier detection and prenatal diagnosis in a number of cases, using a total of 11 polymorphic loci flanking the $D M D$ locus. ${ }^{6}$ Our experience with the many available RFLPs and the large number of DMD families have led us to develop a standardised diagnostic procedure.

Recently Kunkel et $a l^{7}$ described the selective cloning of deleted sequences from a DMD patient (BB, Francke et $a l^{8}$ ) leading to the cloning of sequences at the locus DXS164 (pERT87). In about $8 \%$ of all DMD patients, this sequence (pERT87), or subclones from it, are deleted. ${ }^{10}$ It is likely that pERT87 is located within the $D M D$ region itself, based upon a series of partial deletions at this locus, 
which appear to extend in either direction. The majority of the mutation sites for DMD, mapped by RFLP analysis, are located distal to pERT87. However, at least two $\mathrm{X}$; autosome translocation breakpoints are located proximal to the locus DXS164, and the position of DXS164 relative to all mutation sites is not clear. We have therefore used bridging markers in the DNA probe analysis and, when available, CK levels were used as corroborative evidence. Our results using DNA probes for the diagnosis of Duchenne muscular dystrophy and carrier detection, both pre- and postnatally, are presented in this paper. In addition, the genetic order of loci and linkage data of the DMD probes used, gathered from Dutch DMD families, are presented.

\section{Materials and methods}

\section{PROBES}

In table 1 the probes used are listed with their main characteristics and their sources. Further information about these loci, such as vectors, insert sizes, allele sizes, minor allele frequencies, etc, can be found in the recombinant DNA committee report of the Eighth Human Gene Mapping Workshop held in Helsinki in $1985 .^{12}$

DNA EXTRACTION AND ANALYSES

The DMD families were referred through the seven genetic centres in the Netherlands. Lithium-heparin blood samples were taken from family members and were sent to us within 24 hours. For prenatal diagnosis, chorionic villi taken at the 10th or 11th week of gestation were investigated. The villi of male fetuses were used immediately for DMD diagnosis. Fetal sexing was mainly performed in the cytogenetics unit in Rotterdam by direct chromosome analysis. ${ }^{13}$ Creatine kinase levels were deter-

TABLE $1 \quad X p$ markers.

\begin{tabular}{|c|c|c|c|c|c|}
\hline $\begin{array}{l}\text { Name of } \\
\text { probe }\end{array}$ & $\begin{array}{l}\text { Locus } \\
\text { symbol } \\
\text { (HGM8) }\end{array}$ & $\begin{array}{l}\text { Genetic } \\
\text { distance } \\
\text { to } D M D \\
(c M)\end{array}$ & $\begin{array}{l}R F L P \\
\text { restric- } \\
\text { tion } \\
\text { enzyme(s) }\end{array}$ & $\begin{array}{l}\text { Overall } \\
\text { hetero- } \\
\text { zygote } \\
\text { frequency }\end{array}$ & $\begin{array}{l}\text { Probe } \\
\text { source }\end{array}$ \\
\hline RC8 & $D X S 9$ & $17^{11}$ & TaqI & 0.23 & Davies \\
\hline 782 & DXS85 & $20^{11}$ & EcoRI & 0.50 & Hofker \\
\hline pXUT23 & DXS16 & $18^{11}$ & $B g I I I$ & 0.42 & Willard \\
\hline pD2 & $D X S 43$ & $18^{11}$ & PvuII & 0.40 & Kunkel \\
\hline $99-6$ & DXS41 & $15^{11}$ & PstI & 0.49 & Kunkel \\
\hline B24 & DXS67 & - & MspI & $0 \cdot 15$ & Kunkel \\
\hline $\mathrm{C7}$ & $D X S 28$ & $10^{11}$ & EcoRV & $0 \cdot 25$ & Mandel \\
\hline pERT87 & $D X S 164$ & $2-5^{* 10}$ & Many & 0.9 & Kunkel \\
\hline $\mathrm{XJ} 1 \cdot 1$ & NA & - & TaqI & 0.45 & Worton \\
\hline 754 & DXS84 & $5-12^{* 11}$ & Pst $\mathrm{l} / E c o \mathrm{RI}$ & 0.66 & Hofker \\
\hline cX5.7 & $D X S 148$ & - & MspI & 0.46 & Hofker \\
\hline OTC & OTC & $10^{11}$ & MspI & 0.67 & Fenton \\
\hline $\mathrm{L} 1 \cdot 28$ & $D X S 7$ & $20^{11}$ & TaqI & 0.45 & Bakker \\
\hline
\end{tabular}

*This study.

-No data available. mined in various regional hospitals. The method of Hofker $e t a l^{5}$ was used to extract DNA from total blood and the same method was used to extract DNA from the chorionic villi samples, ranging from 30 to $100 \mathrm{mg}$. DNA samples of 5 to $10 \mu \mathrm{g}$ were digested with the appropriate restriction enzymes (table 1, fig 1) according to the specifications of the manufacturers. Electrophoresis was performed on $0.7 \%$ agarose gels in Tris-acetate buffer, $\mathrm{pH} 7.7$, for 17 hours at 1 volt $/ \mathrm{cm}$. Southern blotting on Gene Screen Plus (NEN) and hybridisation were carried out as described previously. ${ }^{6}$

\section{DIAGNOSTIC PROCEDURE}

Many RFLPs detected by the subclones (pERT87-1, pERT87-8, and pERT87-15) of pERT87 (kindly provided by $\mathrm{L}$ Kunkel) are tightly linked to $D M D$ at approximately $5 \mathrm{cM}$ and are highly informative in DMD family studies, as are the various deletions at this locus. Because of the many RFLPs involved (fig 1), we have chosen a standard diagnostic procedure which always starts with an initial digestion of DNA of all family members using five enzymes, followed by hybridisation with seven probes as shown in table 2 under stage I. These five initial enzymes were selected because of their relative cheapness and then possibility of re-using the blots. In order to obtain as much information as possible to perform carrie detection in the minimum time, we also combine probes into one hybridisation reaction, for example; C7 and pERT87-1, both polymorphic for EcoRV. The EcoRV RFLP for pERT87-1 has not yet been described. It detects a $13 \mathrm{~kb}$ major allele $(70 \%)$ and a $12 \mathrm{~kb}$ minor allele. The first seven probes used were selected on their Xp localisation close to or flanking the $D M D$ locus and also on their heterozygosity frequency. This initial combination gave enough information to establish carrier status in about $50 \%$ of the cases. Where necessary, the five initial blots were rehybridised with additional probes, up to a total of 14 RFLPs (underlined in fig 1), as shown in table 2 under stages I and II. If needed, additional digests were performed so as to make use of other RFLPs (stage III), thus supplying sufficient information to establish informativeness in over $95 \%$ of the cases.

LINKAGE ANALYSIS

Linkage analysis was carried out on a PDP 11 computer using a programme called Myotonia (W S Volkers, 1986, personal communication) which derives lod scores at intervals of 0.01 recombination fraction $(\theta)$ and is based on standard formulae. Recombination frequencies were checked by hand using the maximum likelihood method. ${ }^{14}$ From the individual pedigrees, crossovers between informative 


\section{Telomere}

\begin{tabular}{|c|c|c|c|}
\hline & Loci & Symbols & Enzymes \\
\hline 3.33 & & & \\
\hline $22 \cdot 32$ & $\begin{array}{l}\mathrm{RC} 8 \\
782\end{array}$ & $\begin{array}{l}\mathrm{B} \\
\mathrm{D}\end{array}$ & $\begin{array}{l}\text { TagI } \\
\text { EcoRI }\end{array}$ \\
\hline $22 \cdot 31$ & $\begin{array}{l}\text { XUT23 } \\
\text { D2 }\end{array}$ & $\begin{array}{ll}H \\
E\end{array}$ & $\begin{array}{l}\text { BglII } \\
\text { PvuII }\end{array}$ \\
\hline $22 \cdot 2$ & $\begin{array}{l}99.6 \\
\mathrm{C7}\end{array}$ & F & $\overline{\frac{\text { PstI }}{\text { EcoRV }}}$ \\
\hline $22 \cdot 13$ & B24 & I & $\underline{\text { MspI }}$ \\
\hline $\begin{array}{l}22.12 \\
22.11\end{array}$ & ?DMD, BMD & & \\
\hline $21 \cdot 3$ & IPERT 87.1 & $(K \mid-n)$ & $\operatorname{MspI~(M)}, \operatorname{EcoRV}(P), X m n I(R), B s t X I(S)$ \\
\hline 21.2 & $\quad 87.8$ & $(K I-n)$ & TaqI (K). BstXI (Q) \\
\hline $21 \cdot 1$ & IXJ1.1 87.15 & $\begin{array}{c}(K I-n) \\
U\end{array}$ & $\frac{\overline{T a q I}(\mathrm{~L})}{\mathrm{TagI}}, \mathrm{XmnI}(\mathrm{O})$ \\
\hline 11.4 & $\begin{array}{l}\text { I' ?DMD, BMD } \\
\text { ?DA }\end{array}$ & & \\
\hline 11.3 & 754 & C & \\
\hline 11.23 & $\begin{array}{l}754.11 \\
\text { c } \times 5.7\end{array}$ & N & $\begin{array}{l}\text { EcoRI }(B g(I I=C) \\
\text { MspI }\end{array}$ \\
\hline 11.22 & OTC & $(G 1-4)$ & MspI \\
\hline 11.21 & $\mathrm{~L} 1.28$ & A & $\underline{\text { Taqu }}$ \\
\hline
\end{tabular}

\section{Centromere}

FIG 1 Regional distribution of 13 loci along the short arm of the X chromosome detecting a total of 21 RFPLs. The 14 restriction enzymes underlined indicate the 14 RFLPs covered by the five initial blots (see table 2 stages I and II).

TABLE 2 Diagnostic procedure for each DMD family.

\begin{tabular}{|c|c|c|c|c|}
\hline & \multicolumn{3}{|c|}{ RFLP markers used } & \multirow{2}{*}{$\begin{array}{l}\text { Restriction } \\
\text { enzymes } \\
\text { used }\end{array}$} \\
\hline & $\begin{array}{l}\text { Proximal } \\
\text { side }\end{array}$ & $\begin{array}{l}\text { DMD } \\
\text { region }\end{array}$ & $\begin{array}{l}\text { Distal } \\
\text { side }\end{array}$ & \\
\hline $\begin{array}{c}\text { Stage I } \\
\text { Initial } \\
\text { blots }\end{array}$ & $\begin{array}{l}\text { OTC } \\
\underline{754}\end{array}$ & $\begin{array}{l}\frac{87-1^{*}}{87-15 /} \\
\text { XJ1-1‡ }\end{array}$ & $\frac{\frac{99 \cdot 6 t}{C 7}}{D 2}$ & $\begin{array}{l}\text { MspI } \\
\text { PstI } \\
\text { EcoRV } \\
\text { PvuII } \\
\text { TaqI }\end{array}$ \\
\hline $\begin{array}{l}\text { Stage II } \\
\text { Re-use } \\
\text { blots }\end{array}$ & $\begin{array}{l}\text { CX5.7 } \\
\underline{L 1 \cdot 28} \\
\end{array}$ & $\begin{array}{l}87-1 \\
87-8\end{array}$ & $\frac{\mathrm{RC} 8}{\mathrm{~B} 24}$ & $\begin{array}{l}\text { MspI } \\
\text { MspI } \\
\text { TaqI } \\
\text { TaqI } \\
\text { MspI }\end{array}$ \\
\hline $\begin{array}{l}\text { Stage III } \\
\text { Additional } \\
\text { blots and } \\
\text { re-use }\end{array}$ & 754-11 & $\begin{array}{l}87-1 / 15 \\
87-8 \\
87-1\end{array}$ & $\begin{array}{l}\underline{782} \\
\text { pXUT23 }\end{array}$ & $\begin{array}{l}E c o \mathrm{RI} \\
X m n \mathrm{I} \\
B g I \mathrm{I} \\
B s t \mathrm{NI} \\
B s t \mathrm{XI}\end{array}$ \\
\hline
\end{tabular}

*A new RFLP for 87-1 (EcoRV).

†A subclone of 99.6 was used to lower the background.

$¥ \mathrm{XJ} 1 \cdot 1$ only used in the later pedigrees in combination with $87-15$.

The probe name is underlined when it is used in a combined hybridisation (eg $\mathrm{C7}$ and $87-1$ ).

markers relative to other markers or the $D M D$ locus were scored to establish the most likely order on the $\mathrm{X}$ chromosome.

\section{Results}

CARRIER DETECTION AND PRENATAL

DIAGNOSIS

From the 61 pedigrees investigated (30 familial and 31 isolated cases), we were able to assess carrier status in $75 \%$ of the 136 females at risk (table 3 ) using bridging markers at a maximum distance of 15 cM on either side of the $D M D$ locus. For 68 females we demonstrated non-carrier status with more than $98 \%$ reliability and for 36 females the DMD carrier status on the basis of bridging markers was proven. In 33 of these carriers, there was enough information to offer prenatal diagnosis. Fig 2 (DL12) shows 
TABLE 3 DMD carrier detection using bridging markers.

\begin{tabular}{llll}
\hline $\begin{array}{l}61 \text { DMD families } \\
\text { (30 proven familial) } \\
\text { (31 isolated cases) }\end{array}$ & $\begin{array}{l}\text { Carrier } \\
\text { detection }\end{array}$ & $\begin{array}{l}\text { Prenatal } \\
\text { diagnosis } \\
\text { possible }\end{array}$ \\
\cline { 2 - 3 } & $\begin{array}{l}\text { Reliable } \\
(>98 \%)\end{array}$ & $\begin{array}{l}\text { Not } \\
\text { conclusive }\end{array}$ & \\
\hline 136 females at risk & $\begin{array}{l}68 \text { non-carricr } \\
36 \text { carrier }\end{array}$ & 32 cases & 33 cases \\
& 104 cases & & 65 cases \\
& $(>75 \%)$ & & $(>95 \%)$ \\
\hline
\end{tabular}

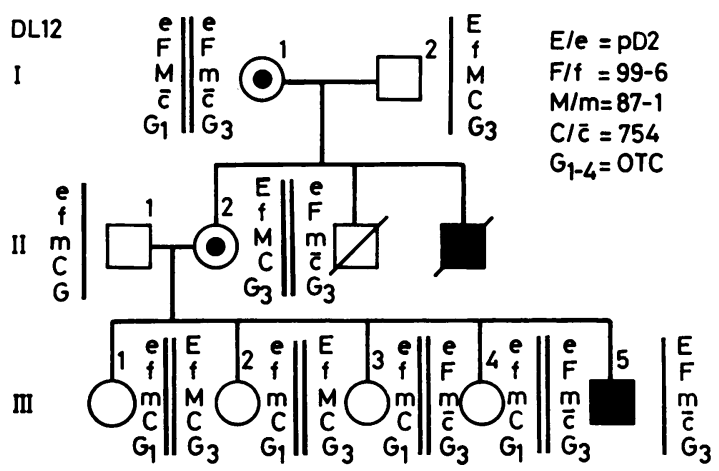

FIG 2 Family DL12, an example of a carrier detection. Subject II. 2 is an obligate carrier informative for $F(99-6)$, $M(87-1)$, and C(754). Subjects III.1 and III.2 are not carriers for DMD (>99\% reliability) on the basis of $F$, $M$, and C. Subjects III.3 and III. 4 are DMD carriers on the basis of $F, M$, and $C(>99 \%$ reliability).

an example of the diagnosis of two carriers and two non-carriers, using the markers 754, pERT87-1 $(M s p \mathrm{I})$, and $99 \cdot 6$. In 32 out of the 136 cases no conclusive statement could be made on the carrier status because (a) there was a detected recombination between the nearest informative bridging markers (17 cases). Fig 3 shows an example (DL85); (b) there was no informative marker on one side of the $D M D$ locus (five cases); and (c) the phase of the 'DMD' X chromosome was unknown, since neither a patient nor healthy male sibs were available (10 cases). However, in those 32 females who had a $50 \%$ risk for DMD carriership, there was sufficient information to discriminate between the potential DMD chromosome and the healthy paternal chromosome and thus to offer prenatal diagnosis (in $95 \%$ of cases). To date, 23 prenatal diagnoses on male fetuses have been performed (table 4). In 16 cases, we were able to provide a diagnosis on the basis of bridging markers. Three were found to be affected and five unaffected with a greater than $98 \%$ reliability (fig 4, DL56). In eight of the pregnan-
TABLE 4 Prenatal diagnosis for DMD using bridging markers.

\begin{tabular}{|c|c|c|c|}
\hline $\begin{array}{l}\text { Diagnosis on } \\
\text { male fetuses } \\
\text { at risk } \\
(23 \text { cases })\end{array}$ & $\begin{array}{l}\text { DMD status of } \\
\text { fetus }\end{array}$ & $\begin{array}{l}\text { DMD carrier } \\
\text { status of mother } \\
\text { (confirmed by } \\
\text { this test) }\end{array}$ & Pregnancies \\
\hline \multirow[t]{2}{*}{$\begin{array}{l}16 \text { cases } \\
\text { (reliability } \\
>98 \% \text { ) }\end{array}$} & 13 unaffected & $\begin{array}{l}1 \text { carrier } \\
4 \text { carrier }(>98 \%) \\
8 \text { non-carrier } \\
\quad(>98 \%)\end{array}$ & $\begin{array}{l}\text { Continued } \\
13 \text { casest }\end{array}$ \\
\hline & 3 affected & 3 carrier ( $>98 \%$ ) & \\
\hline $\begin{array}{l}7^{*} \text { cases } \\
\text { (not conclusive) }\end{array}$ & 7 at risk & $\begin{array}{l}5 \text { carrier }(>98 \%) \\
2 \text { at risk } \ddagger\end{array}$ & $\begin{array}{l}\text { Terminated } \\
10 \text { cases }\end{array}$ \\
\hline
\end{tabular}

*Due to crossover, uninformative markers, etc (see text).

†In seven cases healthy boy born with normal CK levels.

$\ddagger$ In these cases prenatal diagnosis would not have been necessary. if the family material had been sent before the start of the pregnancy.

cies, which had come to our attention in an advanced stage, the prospective mothers proved not to be carriers of the DMD mutation. Seven of the 13 pregnancies diagnosed as unaffected have come to term and all male infants have normal CK levels. In seven out of the 23 prenatal cases we could not draw any conclusions about the DMD risk to the fetus because of recombination between the nearest informative flanking markers (four cases), one possible mosaic Klinefelter case (XXY), insufficient family data (one case), or no informative markers (one case). The latter two groups, as well as the eight in which the mother appeared not to be a carrier, were all cases that came to our attention at an advanced stage of pregnancy. In these cases prenatal diagnosis would not have been necessary had the DNA analysis on the family members been performed earlier. In our material, we detected a deletion in the DXS164 locus in eight out of 67 independent DMD patients. Clearly, in those families, carrier detection and prenatal diagnosis is highly reliable using the pERT87 probe alone.

LINKAGE MAP OF THE DMD LOCUS

Linkage data and physical order of the markers were established from 40 pedigrees of proven familial DMD cases. We obtained lod scores for the Xp markers used relative to the DMD locus. In table 5 the recombination fractions $(\theta)$ at the maximum lod scores are listed with the $95 \%$ confidence limits and the number of informative meioses, sub-divided into known and unknown phase. For the locus DXS84, recognised by the probes 754 and $754-11$, a lod of +12.44 at a distance of $5 \mathrm{cM}$ was found, based on four recombinants in 77 informative meioses. Also on the proximal side of the DMD mutation site(s), the locus $D X S 164$ was found to have a lod of $+10 \cdot 46$ 


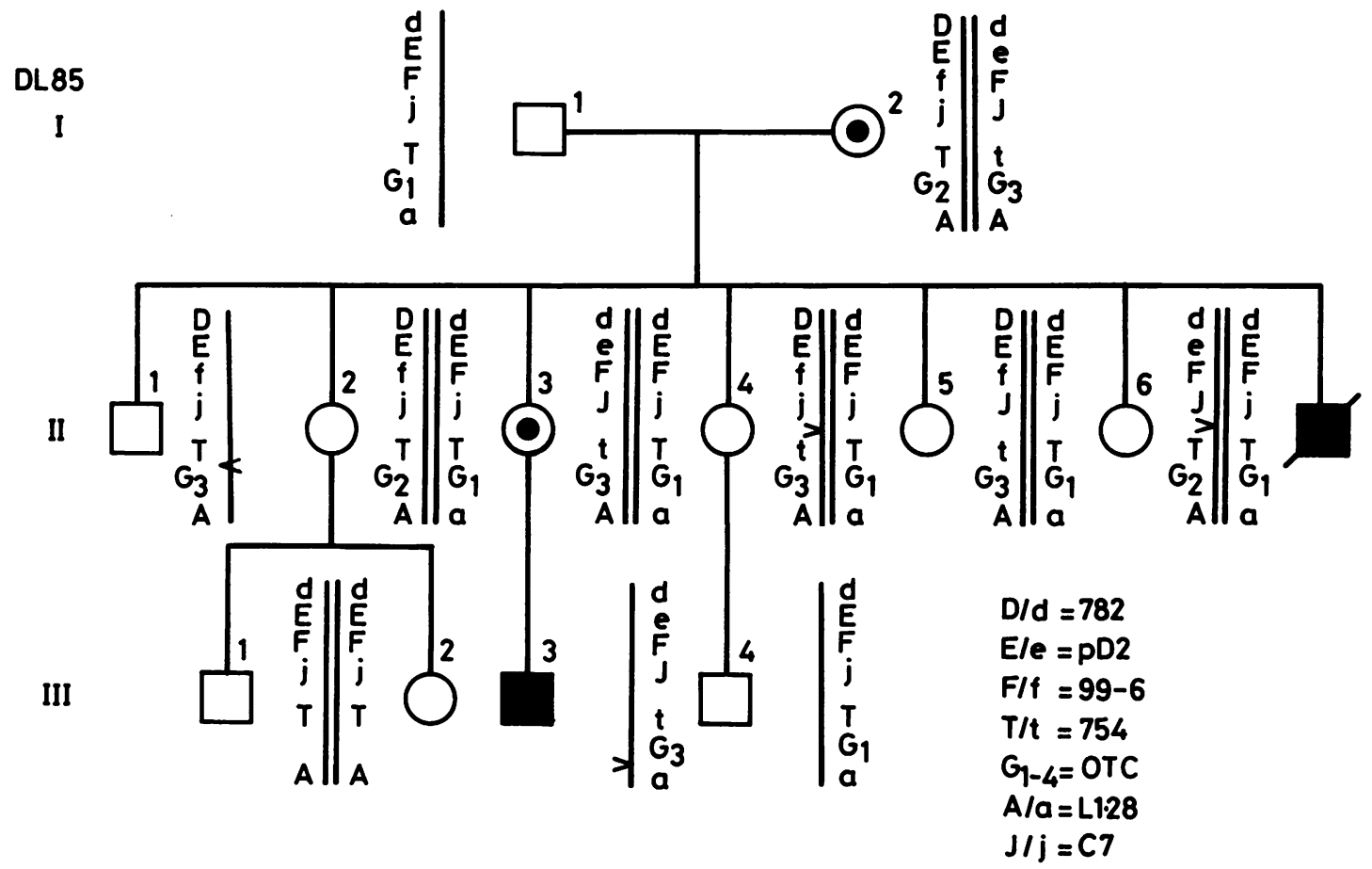

FIG 3 Family D185, an example of carrier detection. Subject II.2 is an obligate carrier, informative flanking markers $C 7(J), 754-11(T)$, and OTC $(G)$. Subject II.1 is a healthy male, crossover between 754 and OTC detected. Subject II.5 is a carrier (>99\% reliability). Crossover detected between $F(99-6)$ and $J(C 7)$ does not interfere with the result. No conclusive result was obtained for subjects II.4 and II.6. In both cases a recombinant was found between C7 and 754-11. Subject II. 4 shows repeatedly raised CK levels, II.6 has normal CK levels. Prenatal diagnosis using flanking markers is possible in all four cases (for the proven carriers II.2 and II.5 using C7 and 754-11; for female at high risk II.4 using 99-6 and 754-11; for female at risk II.6 using C7 and OTC).

at $5 \mathrm{cM}$ (two recombinants in 51 informative meioses). On the distal side, the locus $D X S 28$ or probe $\mathrm{C} 7$ was found to be the closest marker at $7 \mathrm{cM}$ with a lod of +4.31 (two recombinants in 31 informative meioses). The order of the loci on Xp was established by three point crosses (table 6). Of

TABLE 5 Lod scores for DMD and marker loci.

\begin{tabular}{|c|c|c|c|c|c|}
\hline Marker & $\begin{array}{l}\text { Recombinants } \\
\text { phase known }\end{array}$ & $\begin{array}{l}\text { Recombinants } \\
\text { phase } \\
\text { unknown }\end{array}$ & $Z_{\max }$ & $\theta \max$ & $\begin{array}{l}95 \% \\
\text { confidence } \\
\text { limits }\end{array}$ \\
\hline RC8 & 2 in 7 & 0 in 4 & +0.75 & $0 \cdot 18$ & $0.03-0.49$ \\
\hline 782 & 2 in 15 & 10 in 34 & $+2 \cdot 88$ & $0 \cdot 17$ & $0.08-0.31$ \\
\hline pXUT23 & 4 in 8 & 0 in 4 & +0.03 & 0.37 & $0.12-0.50$ \\
\hline pD2 & 6 in 25 & 5 in 21 & +2.27 & 0.23 & $0.13-0.37$ \\
\hline 99.6 & 3 in 23 & 4 in 24 & +3.85 & 0.16 & $0.07-0.29$ \\
\hline $\mathrm{C7}$ & 0 in 10 & 2 in 21 & $+4 \cdot 31$ & 0.07 & $0.01-0.19$ \\
\hline pERT87 & 2 in 40 & 0 in 11 & +10.46 & 0.05 & $0.01-0.12$ \\
\hline 754 & 4 in 35 & 0 in 42 & +12.44 & 0.05 & $0.02-0.12$ \\
\hline OTC & 2 in 16 & 1 in 15 & +3.85 & $0 \cdot 10$ & $0.03-0.24$ \\
\hline $\mathrm{L} 1 \cdot 28$ & 6 in 23 & 1 in 16 & +2.59 & $0 \cdot 18$ & $0.08-0.33$ \\
\hline
\end{tabular}

the four recombinants detected for 754 and $D M D$, three were also informative for pERT87. Two of them occurred between 754, pERT87 and $D M D$ and one occurred between 754 and pERT87, DMD, providing the order 754-pERT87-DMD.

\section{ISOLATED CASES}

We studied families containing an isolated case of DMD. In 12 of these sporadic cases we have information on the origin of the mutation using flanking RFLPs. ${ }^{15}$ In four cases the paternal chromosome was affected and in eight cases either the maternal or grandmaternal chromosome was affected. In four of the eight female origins, meiotic recombination had occurred between pERT87 and the closest informative distal flanking marker, suggesting that mutational events such as unequal crossing over contribute to the relatively high rate of DMD mutation, as was suggested by Winter and Pembrey, ${ }^{16}$ and that there may be a preferential 
TABLE 6 Order of marker loci determined by use of three point crosses (for example, see fig 3 subject II. 2 crossover between L1.28, OTC and 754; subject III.3 crossover between L1.28 and OTC, 754, confirming the order -.--L1.28-OTC-754---.-).

\begin{tabular}{|c|c|c|c|c|c|}
\hline RC8 $782 \quad X U T 23$ & D2 $99.6 \quad C 7$ & $B 24 D M D 87754$ & $5 \cdot 7$ & OTC 1.28 & $\begin{array}{l}\text { Number of } \\
\text { cross overs }\end{array}$ \\
\hline $\begin{array}{c}\mathrm{RC} 8 / / 782 \\
782 / \mathrm{XUT} 23 \\
782\end{array}$ & 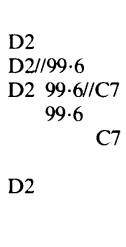 & \begin{tabular}{cr} 
B24// & 87 \\
//DMD & 754 \\
DMD//87 & 754 \\
& $87 / / 754$ \\
\multicolumn{3}{c}{ DMD } & 754 \\
DMD &
\end{tabular} & /I & $\begin{array}{l}\text { OTC } \\
\text { OTC } / / 1 \cdot 28\end{array}$ & $\begin{array}{l}1 \times \\
1 \times \\
3 \times \\
2 \times \\
1 \times \\
2 \times \\
2 \times \\
1 \times \\
3 \times \\
3 \times\end{array}$ \\
\hline
\end{tabular}

RC8-782-XUT23; D2-99.6-C7; B24-DMD-87-754; 5.7; OTC-1.28-cen.

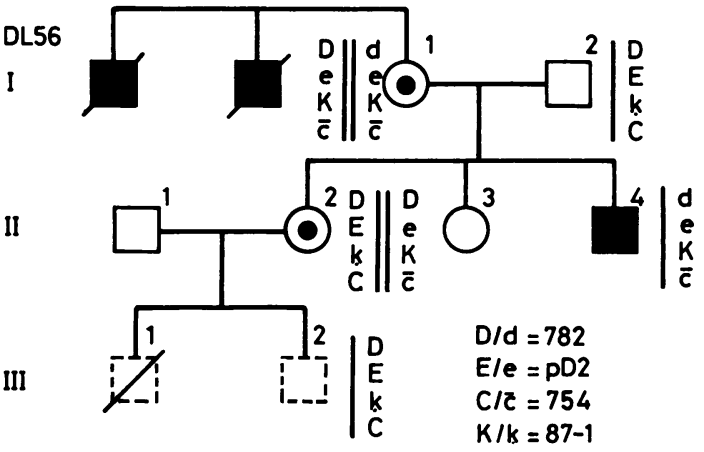

FIG 4 Family DL56, an example of prenatal diagnosis. Subject I.3 is an obligate carrier not informative for available DNA markers except for 782. CK levels not raised. Subject II. 2 is a DMD carrier on the basis of repeatedly raised $C K$ levels. First pregnancy (male fetus III.1, 1984) terminated in the 11th week after sex determination. In 1985 the RFLPs of pD2(E), $p E R T 87-1(M)$, and $754(C)$ were found to be informative in subject II.2. In subject III.2 (male fetus) the grandpaternal X chromosome was detected $(E, k, C)$; therefore he was not affected, the pregnancy continued, and a boy was born in 1986 with normal CK levels.

mutation site distal to pERT87. This is supported by the appearance of a deletion mutation associated with a recombination event occurring in the same meiosis ${ }^{15}$ (fig 1D). The sample size is too small to draw conclusions on whether the male and female contribution to mutation differs. However, the observed 1:2 male:female ratio is approximately what one would expect with equal mutation rates in male and in female derived X chromosomes. ${ }^{17}{ }^{18}$

\section{Discussion}

MAP OF THE DMD REGION

The physical order of loci and the linkage data we obtained in this study (table 5) are not significantly different from published data, ${ }^{11}$ although the genetic distance of $D M D$ from $D X S 84(754)$ reported by various groups seems to vary considerably: from the $5 \mathrm{cM}$ we and other continental European groups have found up to $19 \mathrm{cM}$. Taking into account all reports, as summarised in the Eighth Human Gene Mapping Report (Helsinki), it seems that the average genetic distance of $D X S 84$ is about $12 \mathrm{cM}$. A revaluation of all the data available is therefore clearly indicated, to see if there is heterogeneity of recombination and whether some families contribute far more to the recombination frequency than others.

Recentiy Kunkel et al ${ }^{10}$ reported a major collaboration in which 86 DXS164 deletions from 1201 inde:jendent DMD patients were described. The deietions appeared to extend both distally and proximally from pERT87. From three point segregation data, DXS164 maps proximal to the majority of the DMD mutations. However, cases are also reported where $\mathrm{p} 87$ maps distal to the mutation site (recombinations, translocation breakpoints, or deletion directions). Therefore, pERT87 might be considered as part of the ' $D M D$ locus'. Alternatively, muiations on one side of pERT87 may act through affecting an activity on the opposite side. The same arguments hold true for the $\mathrm{X} ; 21$ translocation junction clones ( $\mathrm{pXJ}$ series) reported by Ray et al, ${ }^{19}$ located between DXS84 and DXS164. As long as uncertainty exists about the position of the DMD mutations relative to $D X S 164$ and $\mathrm{XJ} 1 \cdot 1$, markers should be used that are certain to be flanking the mutation site, except when deletions are detected by either pERT87 or pXJ. As flanking markers, 754 and $\mathrm{C} 7$ currently provide the best combination.

Using pulse field electrophoresis, van Ommen et $a l^{20}$ have estimated that the genomic map of the region involved in muscular dystrophies of the Becker and Duchenne types contain between 1 and 
$4.2 \times 10^{\circ}$ base pairs. A generalised mapping function would suggest that a recombination frequency of $1 \%$ is equal to a physical distance of one million base pairs at the chromosome level. However, around the $D M D$ locus, a $1 \%$ recombination distance apparently corresponds to only $1 \times 10^{5}$ base pairs. The observed high recombination frequency, the deletions, ${ }^{10}$ some of which are correlated with crossing over, ${ }^{15}$ and the $X$;autosome translocations ${ }^{19}$ clearly indicate the genetic instability of the Xp21 region. A number of other examples of genetic instability have been described: in the human $\alpha$ and $\beta$ globin gene clusters ${ }^{21}$ where unequal crossing over gives rise to deletion mutants; the human LDL receptor locus ${ }^{23}$ where Alu sequence mediated recombination causes deletions and duplications; and in the mouse $\mathrm{T} / \mathrm{t}$ complex ${ }^{24}$ where short chromosomal inversions cause illegitimate recombinations.

\section{CARRIER DETECTION AND PRENATAL}

\section{DIAGNOSIS}

Both carrier detection and prenatal diagnosis have proved to be possible with greater than $98 \%$ reliability in about $75 \%$ of cases (pERT 87 deletions not included). DNA analysis using bridging markers alone gives a reliable result in approximately $75 \%$ of cases; this is the inherent risk when using bridging markers between which recombination can occur in a significant proportion of cases. For example, when bridging markers both have a recombination distance of approximately $10 \mathrm{cM}$ with $D M D$, such as DXS84 (754) and DXS28 (C7), then one in five offspring will show recombination. Creatine kinase levels may be extremely helpful, especially where crossovers within the DMD region are detected or no phase information is present.

\section{Conclusions}

We have standardised the procedure for diagnosing DMD with RFLPs by setting up a particular sequence of probes and enzymes with a view to obtaining optimal information with as few restriction enzymes and probes as possible, for example, by rehybridising the blots with more probes to achieve a relatively quick diagnosis (two to three weeks). Assuming that $D X S 164$ is located within the DMD region, the DXS84 locus (754) should be considered to be the closest proximal marker and DXS28 (C7) to be the closest distal marker. Extension of the cloned sequences at the loci bridging the DMD deletion/mutation region, or increasing the heterozygosity at those loci, is needed to improve diagnostic efficiency, which is at present $75 \%$ due to lack of informative RFLPs and recombination events.
We anticipate that cloning of the gene(s) responsible for the Duchenne phenotype will not essentially change the diagnosis of DMD, given that the mutations vary in both size and position. Thus, unless methods are developed to identify rapidly the precise nature of individual mutations in each family affected, the use of flanking RFLP markers will remain the primary diagnostic method, at least for the next few years.

We wish to thank Dr L Sandkuyl, Dr A J v Essen, Mrs I S J v Leeuwen-Cornnelisse, and many Dutch clinicians for referring the DMD families; Drs L Kunkel, W A Fenton, J-L Mandel, R G Worton, $\mathrm{H} F$ Willard, and $\mathrm{K} E$ Davies for supplying the various probes; and Dr W S Volkers for the computer analysis of the data. We are grateful to Miss E Klein Breteler, Miss N Goor, and Mr M P J M Simons for their excellent technical assistance and to Drs $\mathrm{M} \mathrm{H}$ Breuning and $\mathrm{G} \mathrm{C}$ Beverstock for critically reviewing the manuscript. This work was financially supported by The Netherlands Praevantie Fonds, Grant No 28.878 and by The Muscular Dystrophy Group of Great Britain and Northern Ireland.

\section{References}

1 Moser H. Review of studies on the proportion and origin of new mutants in Duchenne muscular dystrophy. In: ten Kate L, ed. Research in the origin and treatment of muscular dystrophy. Amsterdam: Excerpta Medica, 1984.

2 Bullock DG, McSweeny FM, Whitehead TP, Edwards JH. Serum creatine kinase activity and carrier status for Duchenne muscular dystrophy. Lancet 1979;ii:1151.

3 Davies KE, Pearson PL, Harper PS, et al. Linkage analysis of two cloned DNA sequences flanking the Duchenne muscular dystrophy locus on the short arm of the human X-chromosome. Nucleic Acids Res 1983;11:2302-12.

${ }^{4}$ Aldridge J, Kunkel LM, Bruns G, et al. A strategy to reveal high frequency RFLPs along the human chromosome. Am J Hum Genet 1984;36:546-64.

${ }^{5}$ Hofker MH, Wapenaar MC, Goor N, et al. Isolation of probes detecting RFLPs from X-chromosome specific libraries: potential use for diagnosis of Duchenne muscular dystrophy. Hum Genet 1985;70:148-56.

6 Bakker E, Hofker MH, Goor N, et al. Prenatal diagnosis and carrier detection of Duchenne muscular dystrophy with closely linked RFLPs. Lancet 1985;i:655-8.

${ }^{7}$ Kunkel LM, Monaco AP, Middlesworth W, et al. Specific cloning of DNA fragments from the DNA from a patient with an X-chromosome deletion. Proc Natl Acad Sci USA 1985;82:4778-82.

${ }^{8}$ Francke U, Ochs HD, de Martinville B, et al. Minor Xp21 chromosome deletion in a male associated with expression of Duchenne muscular dystrophy, chronic granulomatous disease, retinitis pigmentosa and McLeod syndrome. Am J Hum Genet 1985;37:250-67.

${ }^{9}$ Monaco AP, Bertelson CJ, Middlesworth W, et al. Detection of deletions spanning the Duchenne muscular dystrophy locus using a tightly linked DNA segment. Nature 1985;316:845-48.

${ }^{10}$ Kunkel LM, Hejtmancik JF, Caskey CT, et al. Analysis of deletions in DNA from patients with Becker and Duchenne muscular dystrophy. Nature 1986;322:73-7. 
"Goodfellow PN, Davies KE, Ropers HH. Report of the committee on the genetic constitution of the $\mathrm{X}$ and $\mathrm{Y}$ chromosome. HGM8. Cytogenet Cell Genet 1985;40:296-352.

12 Willard HF, Skolnick MH, Pearson PL, Mandel JL. Report of the committee on human gene mapping by recombinant DNA techniques. Cytogenet Cell Genet 1985;40:360-489.

${ }_{13}$ Sachs ES, van Hemel JO, Galjaard $\mathrm{H}$, et al. First trimester chromosome analysis of complex structural rearrangements with banding on chorionic villi. Lancet 1983;ii:1426.

14 Emery AEH. Duchenne muscular dystrophy: genetic aspects, carrier detection and antenatal diagnosis. $\mathrm{Br}$ Med Bull 1980;36:117-22.

15 Bakker E, Pearson PL. Mutation of the Duchenne muscular dystrophy gene associated with meiotic recombination. Clin Genet (in press).

${ }^{16}$ Winter RM, Pembrey ME. Does unequal crossing-over contribute to the mutation rate in Duchenne muscular dystrophy? Am J Med Genet 1982;12:437-41.

17 Vogel F. A probable sex rate difference in some mutation rates. Am J Hum Genet 1977;29:312-9.

18 Winter RM. Estimation of male to female ratio of mutation rates. Am J Hum Genet 1980;32:582-8.

19 Ray PN, Belfall B, Duff C, et al. Cloning of the breakpoint of an
$\mathrm{X} ; 21$ translocation associated with Duchenne muscular dystrophy. Nature 1985;318:672-5.

20 van Ommen GJB, Verkerk JM, Bakker E, et al. A deletion map covering at least 4 million bp surrounding the human loci for Duchenne muscular dystrophy and glycerol kinase deficiency. Cell (in press).

${ }^{21}$ Goossens M, Dozy AM, Embury SH, et al. Triplicated $\alpha$-globin locus in humans. Proc Natl Acad Sci USA 1980;77:518-21.

22 Weatherall DJ, Clegg JB. Recent developments in the molecular genetics of human hemoglobin. Cell 1979;16:467-79.

${ }^{23}$ Lehrman MA, Schneider WJ, Sudhof TC, et al. Mutation in the LDL receptor: Alu-Alu recombination deletes exons encoding transmembrane and cytoplasmic domains. Science 1984;227:140-6.

${ }^{24}$ Fox HS, Martin GJ, Loyn MF, Herrmann B, et al. Molecular probes define different regions of the mouse $t$ complex. Cell 1985;40:63-9.

Correspondence and requensts for reprints to $\operatorname{Dr} E$ Bakker, Department of Human Genetics, Sylvius Laboratories, PO Box 9503, 2300 RA Leiden, The Netherlands. 